\title{
NUTRIENT REMOVAL BY SUBSURFACE FLOW CONSTRUCTED WETLAND IN THE FARM MEZACIRULI
}

\author{
Linda Grinberga, Ainis Lagzdins \\ Latvia University of Agriculture \\ linda.grinberga@1lu.lv
}

\begin{abstract}
A pilot-scale horizontal subsurface flow constructed wetland was installed at the farm Mezaciruli, Zalenieki county, Jelgava region, in the middle part of Latvia, in August 2014 to improve stormwater quality collected from the farmyard and demonstrate applicability of constructed wetland as a convenient treatment option for contaminated surface runoff. The examined water treatment system consists of a sedimentation pond as a pretreatment plant, a water pump, a water distribution well, and a horizontal subsurface flow constructed wetland with the surface area of $160 \mathrm{~m}^{2}$. During the observation period of 27 months $(2014$ - 2016) water quality parameters such as total suspended solids (TSS), nitrate nitrogen $\left(\mathrm{NO}_{3}-\mathrm{N}\right)$, ammonium nitrogen $\left(\mathrm{NH}_{4}-\mathrm{N}\right)$, total nitrogen $(\mathrm{TN})$, orthophosphate phosphorus $\left(\mathrm{PO}_{4}-\mathrm{P}\right)$, and total phosphorus (TP) were monitored and nutrient removal efficiency of the system was examined. Water samples collected at the inlet and outlet were compared. Monitoring results obtained during this study show that on average concentrations of TN and TP were reduced by $22 \%$ and $80 \%$, respectively. However, nitrate - nitrogen concentrations on average increased by 10\%, as during the time period from June, 2015 to March, 2016 reduction in $\mathrm{NO}_{3}-\mathrm{N}$ concentrations was not observed.
\end{abstract}

Key words: Constructed wetland, Subsurface flow, Nutrients, Stormwater.

\section{Introduction}

When water quality issues in agricultural areas are discussed, mainly the negative impacts of surface runoff and subsurface drainage from arable land, pasture, grassland or wastewater discharge from livestock farming are investigated. Research by Berzina \& Sudars (2010) shows that nutrient concentrations influenced by point source pollution increases in high density livestock farming catchments in Latvia. Results from the long-term monitoring in Latvia show that nitrate concentrations are often higher than the nitrate limit value set by the Nitrate Directive for nutrient leaching from agricultural land (Jansons et al., 2011). The attention should be paid also on surface runoff from farmyards to assess the impacts of territories alongside farm buildings which usually can be described by a smaller catchment area comparing with the extension of agricultural lands. Farmlands may also be artificially drained or equipped with a stormwater handling system. Farmers frequently exploit their farmyards and nearest territories for temporary placing or storage of different agricultural machinery and byproducts. These areas can cause nutrients and suspended solids leakage to waters. In Latvia, which is a member state of the European Union, there is legislation related to the Nitrate Directive 91/676/EEC (1991) concerning storage and use of manure. Still there are not determined any regulations for water quality requirements of stormwater discharged from farmyard territories (LR MK, 2015). Therefore, in most cases stormwaters are directly discharged into streams as a surface runoff or through stormwater handling collector as a point source pollution causing undesirable losses of nutrients and other pollutants to water streams. That runoff may contain high concentrations of organic matter, plant and soil particles, residues from animal feed, litter, remains of mineral and organic fertilizers etc. Stormwater may also contain oil products from agricultural machinery, impurities from manure storage, dust and other dissolved or particulate substances flushed from roofs of agricultural building and other solid surfaces at a farmyard.

To reduce such negative impacts of agriculture on water resources, farmers and regulatory agencies require information on simple, cost-effective tools to control diffuse and point source pollution of watercourses (Tanner, Nguyen, \& Sukias, 2005). In Latvia, it is suggested by regulations to include infield and edge-of-field practices in artificially drained agricultural land to control surface and drainage runoff from agricultural fields in a more environmentally friendly and sustainable way. Interception and biofiltration of surface and subsurface runoff using sedimentation ponds, bottom dams, two-stage ditches, controlled drainage and constructed wetlands (LR MK, 2014) can supplement good agricultural practices to reduce rates of nutrient losses from agricultural lands (Tanner, Nguyen \& Sukias, 2005) The same attention should be focused also on water collected at farmyards. Constructed wetlands may play an important role in reducing nutrient loads to receiving waters (Tuncosiper, 2009; Valkama et al., 2017). Constructed wetland is a well-known nutrient reduction measure as it is a low cost (Heistad et al., 2006) and low maintenance technology used for wastewater treatment around the world (Neralla et al., 2000; Vymazal, 2002), lately this measure is also recognized in Latvia. Choosing constructed wetland as a treatment plant for surface runoff, we should 
comply with variation of discharge and contamination levels that generally depend on precipitation events and operations in a farmyard. Domestic septic systems are generally designed with a pre-treatment system (Heistad et al., 2006; Langergraber, 2007). At the farm Mezaciruli pre-treatment occurs in an open pond, which reduces a peak flow by receiving and compensating weather driven fluctuations of incoming water volume and allows the wetland to operate as evenly as possible. Pre-treatment and primary treatment is combined with elimination of solids (Vera et al., 2011), while subsequent treatment stages consist of a constructed wetland as a natural water treatment technology. The major removal mechanisms of nitrogen in constructed wetlands are nitrification and denitrification (Vymazal, 2002; Tuncosiper, 2009). Subsurface flow constructed wetlands require relatively shorter operation time and additional inputs in comparison to conventional treatment technologies (Vymazal, 2008). Moreover, treatment process can be operated and maintained by personnel without a specific knowledge or education (Garcia et al., 2005). The main purpose of this study is to inspect the treating efficiency of subsurface flow constructed wetland as a wastewater treatment plant under Latvia climate conditions in the pilot site. The objective of the article is to determine if the studied constructed wetland reduces nitrogen and phosphorus concentrations in rainwater.

\section{Materials and Methods \\ Study site}

A horizontal subsurface flow constructed wetland was installed at the farm Mezaciruli (56 $34^{\circ} 22 \mathrm{~N}, 23^{\circ}$ $29^{`} 46$ E), Zalenieki county, Jelgava region, Latvia. The study site is located in the nitrate vulnerable zone made in accordance with the criteria set out in the EU Nitrates Directive (EC, 1991), since intensity of agricultural production throughout the Zemgale region is high. The installation of the constructed wetland in Mezaciruli was started in August, 2014 with a purpose to improve the quality of stormwater collected from the hard surfaces in the farmyard territory. The examined water treatment system consists of a sedimentation pond as a pretreatment plant, a water pump, a water distribution well, and a horizontal subsurface flow constructed wetland with the surface area of $160 \mathrm{~m}^{2}$. A filter material was filled in the subsurface part of the wetland at a depth of $0.9 \mathrm{~m}$ (Fig. 1).

There are $77 \%$ of hard surfaces covering 0.81 ha of the farmyard area, the rest are roofs of the farm buildings. Agricultural equipment and solid manure storage are covered with a polyethylene film and kept in the farmyard under the open sky. Greenhouses for growing vegetables and herbs, biogas plant, livestock buildings and office building are also located in the farmyard. Rainwater from the building roofs and paved area is collected in a stormwater capture wells or gullies and discharged through a close piping system to the sedimentation pond for accumulation and temporal storage, and further distributed to the wetland with the pump. Average concentration of suspended solids at the inlet was $83.36 \mathrm{mg} \mathrm{L}^{-1}$. Color and turbidity of the incoming water visually differ from the water leaving the wetland at the outlet, which shows that the wetland successfully retains suspended solids.

In order to provide suitable conditions for effective wetland performance, which is particularly needed for rainwater treatment, the sedimentation pond before the constructed wetland was built. The dimensions of the sedimentation pond were estimated based on high precipitation events to ensure adequate storage capacity. The designed dimensions for the sedimentation pond are $135 \mathrm{~m}^{2}$ in total area with an average water depth of $1 \mathrm{~m}$. The pipe located at the outlet of sedimentation pond is equipped with a protecting sieve to prevent discharge of coarse material into the distribution well. The pump operates based on a predefined switch-on-tripping system preventing flooding from adjacent areas. Rainwater is discharged into the constructed wetland through a perforated infiltration pipe with the diameter $100 \mathrm{~mm}$.

The surface area of the wetland is $1.2 \%$ of the catchment area. Common reed (Phragmites australis) is the most commonly used plant (Vymazal, 2002) in constructed wetlands because it is easy growing plant in moderate climate, therefore, it is chosen also in

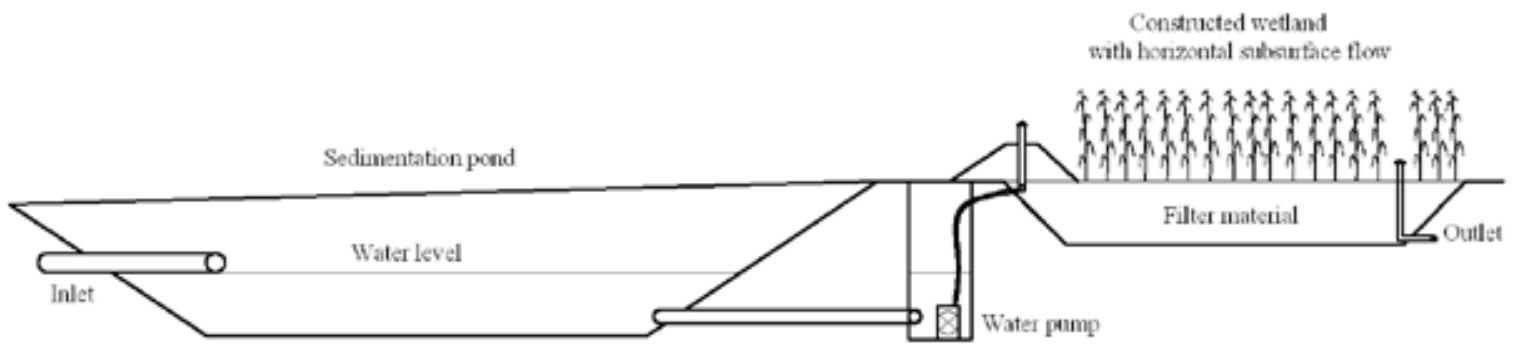

Figure. 1. Schematic drawing of the rainwater treatment system at the Mezaciruli farm. 
Analysis methods, Latvian Standards and equipment for the chemical analysis of water quality parameters

\begin{tabular}{|c|c|c|c|}
\hline $\begin{array}{l}\text { Water quality } \\
\text { parameter }\end{array}$ & Latvian Standard & Analysis method & Equipment title \\
\hline $\mathrm{NO}_{3}-\mathrm{N}$ & FIA, ISO 13395:1996(E) & $\begin{array}{l}\text { Flow analysis (CFA and FIA) and } \\
\text { spectrometric detection }\end{array}$ & \multirow{3}{*}{$\begin{array}{l}\text { AutoAnalyzer Bran+Luebbe } \\
\text { AA-3 }\end{array}$} \\
\hline $\mathrm{NH}_{4}-\mathrm{N}$ & LVS ISO 7150-1:1984 & Manual spectrometric method & \\
\hline $\mathrm{TN}$ & LVS EN ISO 11905-1:1998 & $\begin{array}{l}\text { Method using oxidative digestion } \\
\text { with peroxodisulfate }\end{array}$ & \\
\hline $\mathrm{PO}_{4}-\mathrm{P}$ & LVS EN 1189:2000 & $\begin{array}{l}\text { Ammonium molybdate } \\
\text { spectrometric method }\end{array}$ & \multirow{2}{*}{$\begin{array}{l}\text { Spectrophotometer } \\
\text { GENESYS 10S Vis }\end{array}$} \\
\hline $\mathrm{TP}$ & LVS EN 1189:2000 & $\begin{array}{l}\text { Ammonium molybdate } \\
\text { spectrometric method }\end{array}$ & \\
\hline
\end{tabular}

Mezaciruli. Most frequently used filtration media is gravel and crushed rock with size fractions of $4 / 8$ and 8/16 mm (Vymazal, 2002), in Mezaciruli a filter layer consists of gravel and coarse sand with size fractions of $0.5-5 \mathrm{~mm}$. The bottom part of the wetland is lined with a flexible waterproof membrane to prevent water leaching out of the system (Neralla et al., 2000).

\section{Monitoring of water quality}

To evaluate the efficiency of the rainwater treatment system, water samples were collected using a grab sampling technique at the inlet of the sedimentation pond and at the outlet of the wetland, once or twice per month depending on water discharge. If water flow at the inlet was not observed, water sample was not collected. The monitoring period for this study was from August, 2014 to October, 2016 or 27 calendar months. Water samples were analyzed for concentrations $\left(\mathrm{mg} \mathrm{L}^{-1}\right)$ of total suspended solids (TSS), nitrate nitrogen $\left(\mathrm{NO}_{3}-\mathrm{N}\right)$, ammonium nitrogen $\left(\mathrm{NH}_{4}-\mathrm{N}\right)$, total nitrogen $(\mathrm{TN})$, orthophosphate phosphorus $\left(\mathrm{PO}_{4}-\mathrm{P}\right)$, and total phosphorus (TP) according to the Latvian Standards (Table 1) at the Hydrochemistry Laboratory of Latvian Institute of
Aquatic Ecology. Methods used for the water quality parameter detection are described in Table 1.

To determine whether the nutrient concentrations change significantly after the treatment process in the wetland, data analysis offered by Statistical Package for the Social Sciences (SPSS) program was used.

\section{Results and Discussion}

The existing monitoring data show that the average concentrations of $\mathrm{TN}$ and $\mathrm{TP}$ at the inlet of sedimentation pond are 10.88 and $3.44 \mathrm{mg} \mathrm{L}^{-1}$, respectively. Table 2 summarizes the average values and standard deviations calculated for the water quality parameters at the inflow and outflow of the rainwater treatment system. The results of standard deviations indicate that nutrient concentrations at the inflow and outflow vary greatly. Ammonium-nitrogen concentrations were generally high and quite similar at the inflow and outflow. Almost all of the monitored water quality parameters showed reduction. During the study period the concentrations of TN and TP was reduced on average by a $22 \%$, and $80 \%$, respectively. However, the concentrations of nitrate - nitrogen increased on average by $10 \%$. Notably that during the

Average, standard deviation and reduction values for the water quality parameters

\begin{tabular}{|l|c|c|c|}
\hline $\begin{array}{c}\text { Water quality } \\
\text { parameters }\end{array}$ & $\begin{array}{c}\text { Average concentrations at the } \\
\text { inflow }\end{array}$ & $\begin{array}{c}\text { Average concentrations at the } \\
\text { outflow }\end{array}$ & Reduction, \% \\
\hline $\mathrm{NH}_{4}-\mathrm{N}$ & $1.78 \pm 1.71$ & $1.61 \pm 1.17$ & $\mathbf{- 9}$ \\
\hline $\mathrm{NO}_{3}-\mathrm{N}$ & $2.96 \pm 4.88$ & $3.26 \pm 4.73$ & 10 \\
\hline $\mathrm{TN}$ & $10.88 \pm 8.29$ & $8.49 \pm 4.49$ & $\mathbf{- 2 2}$ \\
\hline $\mathrm{PO}_{4}-\mathrm{P}$ & $2.88 \pm 4.88$ & $0.54 \pm 0.94$ & $\mathbf{- 8 1}$ \\
\hline $\mathrm{TP}$ & $3.44 \pm 5.67$ & $0.67 \pm 1.08$ & $\mathbf{- 8 0}$ \\
\hline $\mathrm{TSS}$ & $83.36 \pm 137.72$ & $32.83 \pm 22.14$ & $\mathbf{- 6 1}$ \\
\hline
\end{tabular}




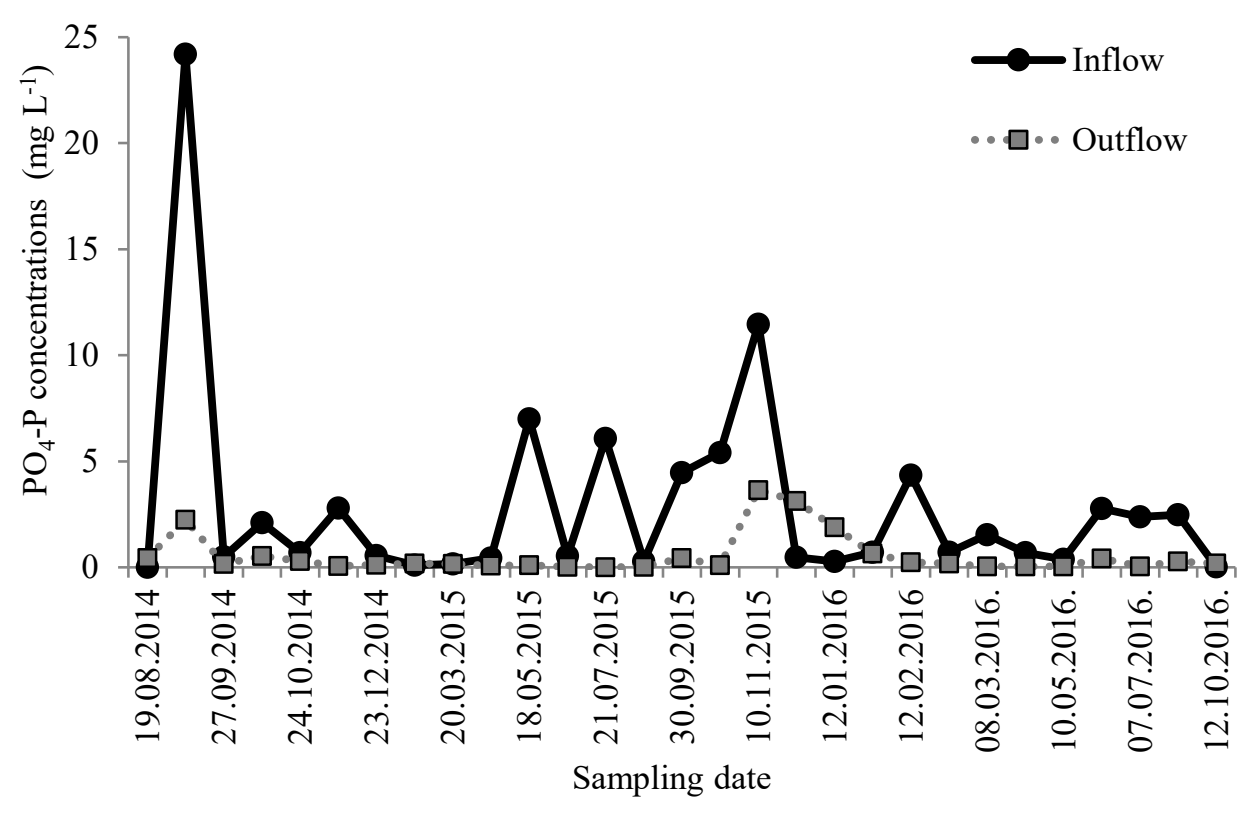

Figure. 2. $\mathrm{PO}_{4}-\mathrm{P}$ concentrations $\left(\mathrm{mg} \mathrm{L}^{-1}\right)$ during the study period.

time period from June, 2015 to March, 2016 reduction in $\mathrm{NO}_{3}-\mathrm{N}$ concentrations was not observed.

To determine whether the nutrient concentrations change significantly after the treatment process in the wetland, ANOVA analysis was used. Null hypothesis was that wetland did not have a statistically significant impact on nutrient concentrations (Valkama et al., 2017). The results of ANOVA analysis showed that TP concentrations at the inflow were significantly different from TP concentrations at the outflow if the statistically significant differences were examined at a significance level of 0.05 . Similarly $\mathrm{PO}_{4}-\mathrm{P}$ concentrations at the inflow were significantly different from $\mathrm{PO}_{4}-\mathrm{P}$ concentrations at the outflow at a significance level of 0.05 . However, the difference was not significant for the concentrations of TN ( $\alpha=$ $0.177), \mathrm{NO}_{3}-\mathrm{N}(\alpha=0.814)$, and $\mathrm{NH}_{4}-\mathrm{N}(\alpha=0.668)$ when results from the inflow and outflow were compared.

Temporal changes in the concentrations of orthophosphate - phosphorus in the rainwater treatment system are presented in Fig. 2. The reduction efficiency depends greatly on the concentration of $\mathrm{PO}_{4}-\mathrm{P}$ measured at the inlet. $\mathrm{As} \mathrm{PO}_{4}-\mathrm{P}$ concentration increases at the inlet, the reduction efficiency decreases. The study of Heistad et al. (2006) showed similar findings. Two episodes supporting this conclusion were observed in September 12, 2014 and November 10, 2015 when the highest concentrations of $\mathrm{PO}_{4}-\mathrm{P}$ at the inlet were measured. In general, the system has performed well with respect to $\mathrm{PO}_{4}-\mathrm{P}$ and TP removal throughout the study period.

The subsurface flow wetland did reduce the concentrations of $\mathrm{TN}$ in $52 \%$ of the sampling events (Fig. 3). The highest concentration of TN, along with the highest reduction rate was observed during the relatively dry period in October, 2015.

One of the factors strongly affecting the performance of constructed wetlands is vegetation (Vymazal, 2002). Garcia et al. (2005) have found that gravel of fine composition promotes greater growth of macrophytes, thus increasing ammonium retention through biomass uptake. Our results also showed that ammonium - nitrogen concentrations had a tendency to increase in vegetation period. The study of Kuschk et al. (2003) demonstrated the similar effect of seasonal temperature changes on the nitrogen elimination rates. Average air temperature during the warm season (April-September) was 13.7 ${ }^{\circ} \mathrm{C}$, while during the cold season (October-March) air temperature decreased to $1.9^{\circ} \mathrm{C}$. Meteorological data obtained from Auce meteorological station.

Ammonium - nitrogen entering the wetland can be transformed into nitrate - nitrogen on the way to the outlet (Xinshana, Qina, \& Denghuab, 2010). When different forms of nitrogen (Wojciechowska, Gajewska, \& Ostojski, 2017) in water sampled at the inflow and outflow are analyzed, an organic form of nitrogen ( $\mathrm{TN}-\mathrm{NH}_{4}-\mathrm{N}-\mathrm{NO}_{3}-\mathrm{N}=\mathrm{N}_{\text {org }}$ ) was $48 \%$ and $46 \%$ for the inflow and outflow, respectively. In contrast, the proportion of $\mathrm{NH}_{4}-\mathrm{N}$ in $\mathrm{TN}$ was $21 \%$ and $22 \%$ at the inflow and outflow, respectively. Similar results were detected also for the proportion of $\mathrm{NO}_{3}-\mathrm{N}$ in $\mathrm{TN}-31 \%$ and $33 \%$ at the inflow and outflow, respectively. These results indicate that nitrogen uptake might be the primary nitrogen removal mechanism in this constructed wetland, but further research is needed to support this statement. Most likely phosphorus is absorbed by the filter material. 


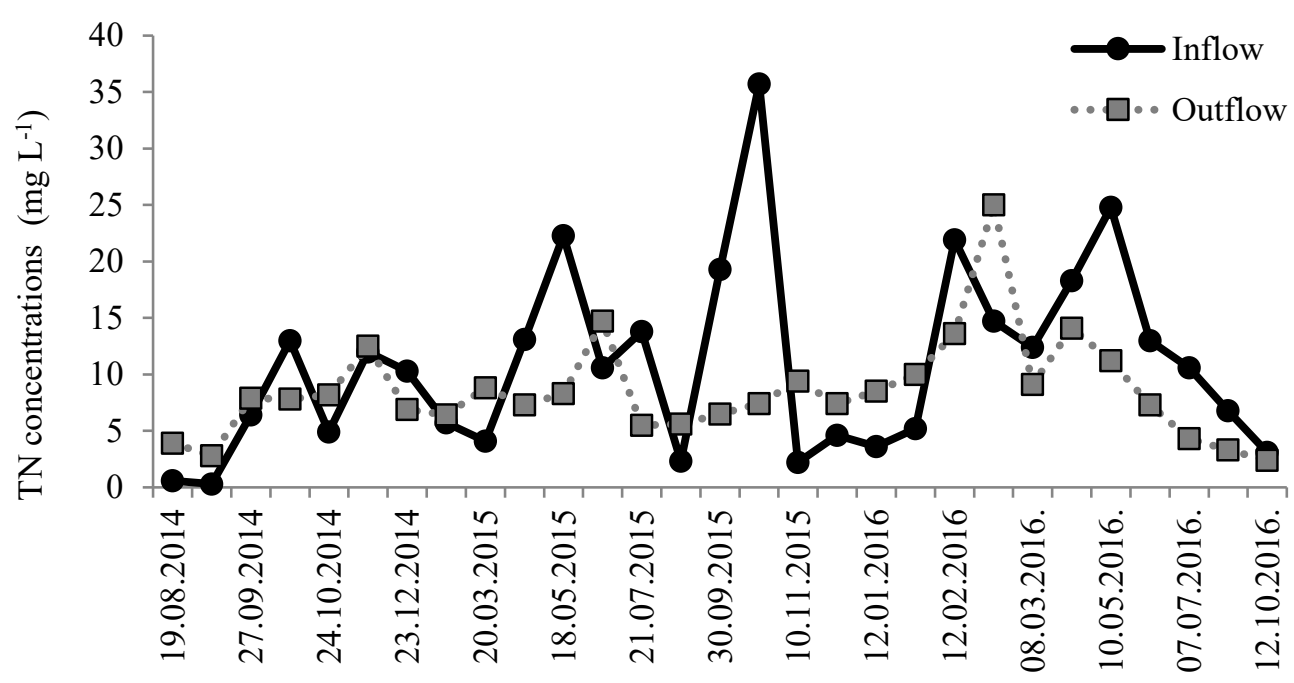

Sampling date

Figure. 3. TN concentrations ( $\mathrm{mg} \mathrm{L}^{-1}$ ) during the study period.

Since the water pump is operated depending on the water level in the sedimentation pond, there may be cases where the water level maintains the pump on operating mode for the prolonged time period. A 19 $\mathrm{m}$ long infiltration tube inside of the wetland currently is able to distribute $0.72 \mathrm{~m}^{3}$ of water. This amount of water can be infiltrated in 17 minutes, limited by the filtration coefficient of the filter material which is 60 $\mathrm{m}$ per day for coarse sand. Extended and intensive rainfall events or rapid snow melting can promote the situation when the surface of the wetland is covered with an open water layer which slowly infiltrates vertically into the filter. Presence of such conditions may negatively affect the efficiency of nutrient removal processes in the wetland.

\section{Conclusions}

This study showed that subsurface flow constructed wetland treating rainwater from agricultural farmyards has a potential to reduce nitrogen and phosphorus concentrations. Higher removal efficiency at the studied wetland was observed for phosphorus compounds as these compounds are mainly retained through physical processes such as filtration and absorption occurring in filter media. The reasons why nitrate - nitrogen concentrations increase after the constructed wetland remain an open question. Overall, additional and more detailed investigations are needed to understand processes behind nutrient removal in subsurface flow wetlands.

\section{Acknowledgements}

This study was financially supported by the European Union, the European Regional Development Fund, and the Central Baltic Programme project CB295 'Practical actions for holistic drainage management for reduced nutrient inflow to Baltic Sea (NUTRINFLOW)'.

\section{References}

1. Berzina, L., \& Sudars, R. (2010). Seasonal Characterization and Trends Study of Nutrient Concentrations in Surface Water from Catchments with Intensive Livestock Farming. Scientific Journal of Riga Technical University, Environmental and Climate Technologies. Volume 5, 8-15.

2. EC (1991). Council Directive 91/676/EEC of 12 December 1991 concerning the protection of waters against pollution caused by nitrates from agricultural sources. Official Journal of the European Communities, No. L375, $1-8$.

3. Garcia, J., Aguirre, P., Barragan, J., Mujeriego, R., Matamoros, V., \& Bayona, J. (2005). Effect of key design parameters on the efficiency of horizontal subsurface flow constructed wetlands. Ecological Engineering 25, $405-418$.

4. Heistad, A., Paruch, A., Vrale, L., Adam, K., \& Jenssen, P.D. (2006). A high-performance compact filter system treating domestic wastewater. Ecological engineering 28, 374 - 379.

5. Jansons, V., Lagzdiņš, A., Bērziņa, L., Sudars, R., \& Abramenko, K. (2011). Temporal and Spatial Variation of Nutrient Leaching from Agricultural Land in Latvia: Long Term Trends in Retention and Nutrient Loss 
in a Drainage and Small Catchment Scale. Scientific Journal of Riga Technical University. Series 13: Environmental and Climate Technologies, Vol.7. ISSN 1691-5208, 54 - 65.

6. Kuschk, P., Wiexner, A., Kappelmeyer, U., WeiXbrodt, E., Kastner, M., \& Stottmeister, U. (2003). Annual cycle of nitrogen removal by a pilot-scale subsurface horizontal flow in a constructed wetland under moderate climate. Water Research 37, 4236 - 4242.

7. Langergraber, G. (2007). Simulation of the treatment performance of outdoor subsurface flow constructed wetlands in temperate climates. Science of the Total Environment 380, 210 - 219.

8. LR MK (2014). Ministru kabineta noteikumi Nr.600. Kārtība, kādā piešķir valsts un Eiropas Savienības atbalstu atklātu projektu konkursu veidā pasākumam 'Ieguldījumi materiālajos aktīvos'. (The procedure for granting the state and the European Union's support for an open project competition in the form of the measure 'Investments in tangible assets') Riga. (in Latvian).

9. LR MK (2015). Vides monitoringa programma 2015. - 2020. gadam. (Environmental monitoring program 2015 - 2020). II Ūdeņu monitoringa programma. Riga. (in Latvian).

10. Neralla, S, Weaver, R.W., Lesikar, B.J., \& Persyn, R.A. (2000). Improvement of domestic wastewater quality by subsurface flow constructed wetlands. Bioresource Technology 75, $19-25$.

11. Tanner, C.C., Nguyen, M.L., \& Sukias, J.P.S. (2005). Nutrient removal by a constructed wetland treating subsurface drainage from grazed dairy pasture. Agriculture, Ecosystems and Environment 105, 145 - 162.

12. Tuncosiper, B. (2009). Nitrogen removal in a combined vertical and horizontal subsurface-flow constructed wetland system. Desalination 247, $466-475$.

13. Valkama, P., Mäkinen, E., Ojala, A., Vahtera, H., Lahti, K., Rantakokko, K., Vasander, H., Nikinma, E., \& Wahlroos, O. (2017). Seasonal variation in nutrient removal efficiency of a boreal wetland detected by high-frequency on-line monitoring. Ecological Engineering 98, 307 - 317.

14. Vera, I., Garcķa, J., Sịez, K., Moragas, L., \& Vidal, G. (2011). Performance evaluation of eight years experience of constructed wetland systems in Catalonia as alternative treatment for small communities. Ecological Engineering 37, 364 - 371.

15. Vymazal, J. (2008). Constructed Wetlands for Wastewater Treatment: A Review. Proceedings of Taal 2007, The 12thWorld Lake Conference, 965 - 980.

16. Vymazal, J. (2002). The use of sub-surface constructed wetlands for wastewater treatment in the Czech Republic: 10 years experience. Ecological Engineering 18, 633 - 646.

17. Wojciechowska, E., Gajewska, M., \& Ostojski, O. (2017). Reliability of nitrogen removal processes in multistage treatment wetlands receiving high-strength wastewater. Ecological Engineering 98, 365 - 371.

18. Xinshana, S., Qina, L., \& Denghuab, Y. (2010). Nutrient Removal by Hybrid Subsurface Flow Constructed Wetlands for High Concentration Ammonia Nitrogen Wastewater Procedia. Environmental Sciences 2 , $1461-1468$. 